\title{
The Unity of Culture: A New Reading in Javanese Traditional Poetry
}

\author{
Nur Ahmad ${ }^{1}$, Akhmad Arif Junaidi $^{2}$ \\ Universitas Islam Negeri Walisongo Semarang ${ }^{1,2}$ \\ \{n.ahmad@walisongo.ac.id ${ }^{1}$, arif_junaidi@walisongo.ac.id²
}

\begin{abstract}
This paper argues for the existence and demonstrates the way of composing macapat in Javanese Islamic tradition. It examines several not fully explored texts in several early modern Javanese manuscripts written by pesantren agents. To examine those manuscripts which were written roughly in the range from 1700-1900, the research starts with philological study. Then, it employs the framework proposed by Davaney [1] in analyzing the dynamic process of culture. In conclusion, the paper shows that not only does macapat exist in pesantren, the Islamic traditional education body has also played an important role on the dissemination of the traditional song especially for transmission of religious teachings. The research also discovers that the agency of pesantren actors to popularize Arabic kitabs and to ease the process of study those books leads to the rendering Arabic kitabs into macapat in Javanese. Thus, this paper shows that the pesantren tradition is part of the formation of what is called "Javanese culture".
\end{abstract}

Keywords: Culture; Tembang Macapat; Pesantren Tradition; Javanese Literature; Islamic Manuscript

\section{Introduction}

The popularity of macapat in the Javanese society cannot be more emphasized. Geertz [2, p. 282] visualized that in the rural areas, "You cannot walk from one end of Modjokuto to the other after ten at night and not hear someone singing a tembang somewhere along the way". Ronggasasmita in [3, pp. 1-2] provided an account on texts usually read by elites of the palace.

"I saw [him] on those nights

When he had no guests

Once resting from his writing

Nothing else was seen by him

Aside from suluk and sufi texts"

In remembering R. Ng. Yasadipura I (1729-1803), Ronggasasmita recalled only two types of works with the same materials that his grandfather read every night. Suluk and Tasawuf refer to the teachings of Sufism. They differ only in the way of conveying the teachings, 
otherwise the naming of both in the poem above is illogical. Suluk is always in macapat in Javanese language. Meanwhile, tasawuf here refers to Arabic sources of the teachings elaborated in suluk literatures.

The account above also shows two important issues on the relation between macapat and religion. First, it reveals how importance of composing macapat containing religious theme is. Darusuprapta $[4$, p. 16] explains that religious teachings are the foundation on which history, arts, and law literatures are based. These four concepts build the realm of the Javanese thought. Therefore, macapat's principal purpose is as a means of communication between the people here in the world and the unseen world. Macapat is the language employed to embody Javanese faith to the power of God. Kartomi [5, p. 9] and Suparto [6, p. 73] identifies several communal ceremonials (slametan) in which certain macapat text is sung, including "moving into a new house", "planting or harvesting of rice", "celebration of a seven-months pregnant woman", and akékah ceremony, in which "a new-born baby's hair is cut" and parents give the baby a name. In all of the ceremonials, the select macapat texts which are sung or read contain symbolical language of prayer that the new house will give the grace to the dwellers, the baby grows up in safety, and the fetus is protected from any calamities.

Second, not only is the religious theme important but also the canonical books in Arabic are sources of macapat songs. In Ronggasasmita's account above, it corroborates the notion that Arabic books in the Islamic metaphysical tradition are rendered into traditional genre in Javanese language and traditional poetical genre. This process of rendering from Arabic into Javanese could be seen as the world making process of interpreting Islam into the new context, Javanese context. The new context of meaning is marked by, not only many loanwords but also the rise of new symbols containing the same Islamic meanings.

The concept of symbolic language in a macapat may be seen as a local expression of Islamic invocation (dhikr). ${ }^{1}$ A specific text continuously read and sung in a specific ceremony will produce such a deep effect on the heart of the reader and the listener. The final fruit of the invocation of various God's Names related to human conditions seen in the frame that God is the Creator of all of these is reaching the Truth which deeply penetrates into human soul.

Prayer is an essential concept in every religion. When a prayer is sent up in the Javanese language which contains the same sense as in Hindu-Buddhic time, it does not mean that the syncretism exists. To whom the prayer is uttered decides the religion of the people. In the opening Kidung Rumekso Ing Wengi which is ascribed to Sunan Kalijaga, the author prays:

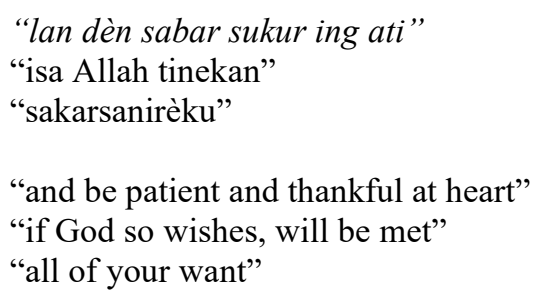

The grace from the reciting the Name of God is believed to be channeled to the listeners, readers, and singers of the macapat. In addition to bridge the spiritual world with the profane world, categories unknown for the traditional Javanese people which are stated here to adopt the modern minds, macapat also functions as a means of making the religious teachings popular among lay people. They may sing macapat in leisure as Geertz suggested. Some suluks are avaiable so select to sing in the wayang performance. The lay people, in many occasions, have more opportunity to listen to macapat rather than to prose. In Suluk Tuhfah, as 
I will elaborate more below, the author explains the goals of a composing macapat, including penetrating the teachings into human soul, and creating wide-open access to the teachings for the general people.

The themes covered in macapat do not limit to 'spirituality' in specific sense this word display today. Several macapat themes, including the genealogy of the kings, the historiography of the kingdoms, and the law of customary manners, are more inclined to political ideas than the spiritual ones. They function mainly to preserve and to transmit history of Javanese tradition [7, p. 121]. The same conclusion is also applied to the macapat with themes on the forming of children's characters, the fictional narrative, personal journal stories, and even humor. Reading them with today's point of views, however, will break the unity feature of Javanese tradition. The traditional society in which macapat was born do not have that segregated concept between the profane and the spiritual. In the traditional society, all the conditions of human life are a mode of God's manifestation. For example, in macapat with humor, which is called cangkriman, various messages from instilling appropriate manners to the mystical ideas are hidden in the funny phrases. The messages will always be concerning to live a life as God's will.

Kartomi [5, p. 5] showed that the worlds reflected in tembang macapat include the IndianJavanese cultural contact, the impact of Islam, and the rise of Western colonialism. However, she [5, p. 14] restricted the main developer of tembang macapat to the courts. Previous scholars also indicate that the tradition of composing macapat is under the hegemony of Javanese court poets [6, p. 75], [8]-[10]. In the academic discussion on the traditional Javanese poetry, no studies, as far as I could refer, try to showed the composer of macapat originated from the outside agency. Take for example the tendency to disowned the role of pesantren tradition in the dissmenation of tembang macapat. There is a tendency to make a dichotomy between the Javanese literary tradition cherished in pesantren and Javanese palaces. Jamil $[9$, p. 28] supports this separation by the theory of clash between santri and Javanese artists. He [9, p. 29] leaps to conclusion that the pesantren primarily develops the syi'ir tradition, not other genre. In similar vein, Darnawi [11, p. 82], Effendy [8, p. 60], and Saddhono and Pramestuti [12, p. 19] identify that the only literary tradition kept alive in pesantren is syi'ir.

This article is a humble effort to shed light on the notion that Javanese literary tradition has been cherished not only inside the wall of the palace but also outside of it [13], [14]. In this article I examine some texts contained in some unfully explored manuscripts in the notion that they are composed in the pesantren tradition. The literary genre of pesantren, therefore, is not limited only to syi' ir as believed so far. This fact is a means of essential analysis on where, how, and why a macapat text was composed outside the courts. This article employs a notion of cultural analysis, as stated by Davaney $(2001,5)$, that instead of viewing culture as "accumulation of knowledge or meaning produced by elites... culture now is viewed as the dynamic and contentious process by which meaning, and with it power, is produced, circulated, and negotiated by all who reside within a particular cultural milieu." Giving the necessary analysis of the cultural agency outside of the palace, that is the pesantren tradition, is an important way to give clearer view of the "traditional Javanese literature", especially on the role of the sub-culture generally marginalized in scholarly discussions so far.

\section{Results and Discussion}


The main text will be discussed to support my thesis has been already referred to above. Before I discuss the features of Suluk Tuhfah to give clue on how and where the text was composed, I will analyze manuscripts of the Arabic sources of the macapat text and several philological issues relating to them. The existents of those manusripts in pesantren tradition will shed lights on the unbroken chain of transmission and the widespread circulations of ideas contained in Tuhfah.

Suluk Tuhfah is an adaptation into macapat which is based on Arabic Tuhfatul Mursalah ilā an-Nabi "The Gift Addressed to the Prophet". Fathurrahman [15, p. 182] believed that the Arabic Tuhfah was finished in 1590. Its' author was Syaikh Muhammad bin Faḍlullāh alHindī al-Burhanfūrī (d. 1029 H/ 1619 A.D.). Otto Loth [16, pp. 191-192;185-186] informed that Al-Burhanfūrī was a student of Syaikh Wajīhuddin bin Qāḍi Nașrullāh 'Alawī (910-998 H/1504-1589 A.D.) and the great Syaikh Muhammad bin Khațīuddin Husainī (d. circa 970 H/1562 A.D.), who was better known as Syaikh al-Gaus, the author of the great sufi work alJawāhirul Khamsah and also the descendant of another great sufi master Khawājah Farīduddīn 'Atțār (d. 1229 A.D.). Voorhoeve [17, p. 126] stated that al-Burhanfūrī was also a close friend of Sibghatullah bin Ruhillah al-Baruhi al-Madani. Voorhoeve [17, p. 126] also gave acoount that Hikayat Aceh mentioned the last name above dwelling in Mecca and having relation to pilgrims from Aceh. Except Khawājah Farīduddīn 'Atțār, all belonged to the Shattariya order which would be preached by Ahmad al-Kushashi to Abdur rauf singkel who later preached this sufi order in Indonesia.

Arabic Tuhfah presents a picture of the literacy in the Islamic scholarly tradition in the archipelago. Being composed at Mecca in 1590, it is not impossible, as earlier mentioned by Johns [17], that the teachings of Tuhfah arrived and became popular in the archipelago in the author's lifetime. At least, it must be read by the people of the archipelago before Abdurrauf Singkel visited Arabia in 1645 since there was fierce debate on the teachings of wujudiyah as found in Tuhfah between the keen followers and the vociferous opponents led by ar-Raniri $[18$, p. 71$]$. For this reason, as suggested by Fathurrahman [15, p. 181], Abdurrauf posed a question concerning teachings on this book to his master at Medina, the murshid of Shattriya order after and the the son in law of al-Kushashi and, Ibrahim al-Kurani [19, p. 18]. Answering his pupil, al-Kurani wrote a Sufi treatise entitled Ithāf al-dhakī bi sharh al-tuhfah al-mursalah ilá al-nabì śallallāhu 'alayhi wa-sallama (Tribute to a pure soul: an elucidation of the gift that was bestowed upon the Prophet). In his commentary, al-Kurani mentioned that the Arabic Tuhfah had been popular in the archipelago and had caused confusions among lay people so some of them left the guidance of the prophet Muhammad saw.

However, Johns and Voorhoeve [17] missed some important aspects of the Arabic Tuhfah studied in Indonesia. Even though Voorhoeve [20, p. 380] described that all manuscripts of the Arabic Tuhfah he consulted were provided with interlinear translation, some even with complex marginal glosses, it is questionable that he did not elaborate further this fact. A further analysis to this fact will complete the puzzle on the study of macapat Suluk Tuhfah. The corpus of Arabic Tuhfah including its commentares (syarah) with its local languages interlinear and marginal glosses will open new discussions to the Suluk Tuhfa. The manuscript with code Or. 5690 is a collection of Leiden University Library. The material of the manuscript is treebark paper (dluang, Javanese) [21, p. 187]. The manuscript is in fair physical condition. It contains 147 folios. Even though worms ate many pages, fortunately it happened only in the blank part in the bottom and the top margin area. All texts in general is in excellent condition to read. The text is written in Arabic and Pegon scripts employing naskh style of writing. 
In addition to a complete Arabic Tuhfah, the manuscript also contains several texts of mystical treatises. In contrast to the claim of Jan Just Witkam [21, p. 187] who mentioned nineteen texts, my consulting to the manuscript shows that the manuscript contains twenty-two different texts. They include twenty-one Arabic mystical treatises with glosses in Javanese, and one Javanese text (r. 59) containing exposition on appropriate times for having sexual intercourse based on the wife's skin color. Our manuscript also shows a feature exclusive to pesantren tradition. The process of giving interlinear translation to the Arabic text, which is called "bandongan" or "weton", is the main feature of study process in pesantren tradition. The process is illustrated as a "kiai" reading and translating a text to whom several "santris" listening and giving notes on words they do not know [22, p. 21]. Often, a kiai provides elaborated explanations written by santris as marginal glosses in their own copy of the text. Most of surviving manuscripts from pesantren tradition could be known from this process.

This is what happened also to the Arabic Tuhfah which is situated in $96 \mathrm{v}$. to $103 \mathrm{v}$. of MS. 5690. It is also completed with several additional glosses to the Arabic text, such as in $96 \mathrm{v}$. and $99 \mathrm{v}$. The text shows that it was studied by senior santri as can be seen from the unvocalized Arabic and Pegon scripts. In addition, the translation is only given here and there, showing that the santri already knew the meaning of many Arabic words. Not only in Javanese, the study of Arabic Tuhfah also happened in Malay. The manuscript with code A 696 kept in Perpustakaan Nasional Indonesia bears witnesses how the study of the text happened in the greater part of the archipelago since Javanese and Malay languages are two dominant languages of the people of this archipelago. This manuscript contains some mystical treatises, mostly from the school of Ibnu 'Arabi (d. 1240). The first text in this manuscript is the Tuhfah which is completed with Malay interlinear translation and glosses.

In addition, the manuscript with code Or. 7236 bears witness how the study of the text was popularized in other form. The translation here is given not as interlinear. Instead, each sentence or in some occasions phrase will be followed by their translation in Malay. In pesantren tradition today, this style would be employed only to the popular text studied by santri. The goal of this format is to deliver the complete idea of the text and to make it easier to understand in compare to the interlinear translation to which a santri should have some knowledge on Arabic grammar. In Javanese context, a prolific kiai who write this kind of composition is Kiai Sholeh Darat (d. 1903) [23].

Further evidence of the popularity of Tuhfah is the existence of its' commentaries to study in the pesantren tradition. It is a tradition in pesantren community that an important text will be more examined from their commentaries (sharah), and even commentaries of commentaries (hashiyah). This practice serves as a digging tool of gaining complex understanding of a text [24, pp. 125-132]. There are three commentaries to the Tuhfah known to exist. The earliest commentary was composed by al-Burhanpuri himself which is entitled al-Haqiqa al-Muwaffiqa li al-Shari'a. This text is known in Indonesia at least from the end of $17^{\text {th }}$ century. The manuscript A 696 above contains a cover of this commentary. This page must be followed by texts dedicated for the commentary but never happened. It is difficult to certain of the reason for this missing, whether the pages are missing out or the santri who wrote it had the intention to study the text but he/she never realized to do it.

However, the study of the text was actually happened in Indonesia. A Leiden Manuscript with code Or. 7022 shows this process. According to Voorhoeve [20, p. 37], the manuscript comes from the $18^{\text {th }}$ century of Bengkulu, Sumatra. The existence of this manuscript bears witnesses the continuity study of Tuhfah from the $17^{\text {th }}$ century to $18^{\text {th }}$ century. The study of a commentary is done by higher level of santri. In this case, it is shown from the use of Arabic to give interlinear translation and commentary to the Arabic text. 
The second commentary is Ithāf al-dhakī bi-sharh al-tuhfah al-mursalah ilá al-nabī śallallāhu 'alayhi wa-sallama. This commentary is written by Ibrāhīm ibn Hasan al-Kūrānī alShahrazūrī al-Shahrānī al-Kurdī al-Madanī al-Shāfi' '̄ (1616-1690 CE) for the Javanese society who were struggling with the debate about the teachings of tuhfah. Fathurrahman has studied 17 manuscripts of Itha $\bar{f}$ al-dhaki for his edited publication and translation [25]. However, he missed some essential points especially in the existence of Ithăf al-dhaki and its' relation to the general discourse of Wahdatul Wujud in pesantren tradition.

Even though it is certain that the composing of Itha $\bar{a} f$ al-dhaki was as an answer to the confusion caused by Tuhfah in Indonesia, I wonder why the commentary was hardly known in the archipelago. Fathurrahman [25, pp. 24-26] mentioned that from 31 copies of Ithāf al-dhaki he managed to find, only one manuscript was identified as written in Malay-Indonesia world. In addition, instead of Ithăf al-dhaki, the people of the archipelago usually make reverence directly to Tuhfah. For example, Kiai Shaleh Darat, a prolific author in the $19^{\text {th }}$ century Java, warned the common people from reading books composed for spiritual elites such as Jili's insan kamil and Burhanpuri's Tuhfah.

For these reasons, I doubt Fathurrahman's claim [25, p. viii] that Syekh Abdur Rauf Singkel was probably the one who proposed to al-Kurani to write this commentary. Al-Kurani himself mentioned that it was from the "reports of the group from Malay-Indonesia world" that he knew the problem caused by "some books on Nature and Secret of the Truth". Not many names from his "jamaah jawiyyin" could be mentioned for sure. Only two of them, so far, are commonly attributed as his students. In addition to Abdul Rauf, Syekh Yusuf alMakassari is also his student. There no sound argument to attribute the group of MalayIndonesia people mentioned by Kurani to Abdul Rauf or Yusuf al-Makassari.

The last commentary of Tuhfah is so important to mention. The title of the commentary is Al-Mawahib Al-Mustarsalah Ala Al-Tuhfah Al-Mursalah. Yahya [26] carried out a philological study of this text. He succeeded in editing and preparing the translation of the text. However, in the context of our study, this text needs more study. The text is contained in manuscript with code A 97 which is kept in Perpustakaan Nasional Republik Indonesia. More detailed hard information on this manuscript could be consulted to Yahya's translation. Here, it is more important to point out to some facts and propose some notions based on those fact.

A 97 shows also a process of learning developed in pesantren which is exclusively characterized by giving interlinear translation. Here the Javanese translation is more important to stress because Mawahib was written by an ulama from nusantara. Yahya [26, p. 248] tends to believe that the author of this commentary is Ibrahim b. Abi Bakr asy-Syami al-Azhari alAsyi asy-Syafi'i. If his analyzing is correct, so it marks the more complex transmission of Tuhfah's teaching because the last name was said to come from Suriah and taught in Aceh in . The circulation of the book covered a large area connecting the Malay world to the Javanese world. In other words, the teaching of tuhfah and his commentary were so important so every possible explanation on this teachings would be brought into attention in a process of learning in Javanese pesantren.

\section{Conclusion}

Taking all the manuscripts of Tuhfah and its corpus above, their circulations directly relates pesantren traditions in Java to the greater part of Islamic world in Malay and Arab. Such perfect precondition leads to the composition of Suluk Tuhfah in tembang macapat. In conclusion, the paper shows that not only does macapat exist in pesantren, the Islamic 
traditional education body has also played an important role on the dissemination of the traditional song especially for transmission of religious teachings. The research also discovers that the agency of pesantren actors to popularize Arabic kitabs and to ease the process of study those books leads to the rendering Arabic kitabs into macapat in Javanese. Thus, this paper shows that the pesantren tradition is part of the formation of what is called "Javanese culture".

\section{Acknowledgments}

This work would not be possible without the study funding awarded to me by Ministry of Religious Affairs of Indonesia in 2016-2017 in which period I took my master's at Vrije Universiteit Amsterdam. In this great opportunity, I collected data manuscripts analysed here from Leiden University Libraries.

\section{References}

[1] S. G. Davaney, "Theology and the Turn to Cultural Analysis," in Converging on Culture: Theologians in Dialogue with Cultural Analysis and Criticism, Oxford: Oxford University Press, 2001, pp. 3-16.

[2] Clifford. Geertz, The Religion of Java, Phoenix ed. Chicago: University of Chicago Press, 1976.

[3] N. Florida, Writing the Past, Inscribing the Future: History as Prophecy in Colonial Java. Durham, 1995.

[4] Darusuprapta, "Macapat dan Santiswara," Humaniora, no. 1, pp. 15-39, 1989.

[5] M. J. Kartomi, Matjapat Songs in Central and West Java. Canberra: Australian National University Press, 1973.

[6] Suparto, "Tembang Macapat sebagai Sumber Ide Gending-gending Karya Ki Nartosabdo," Selonding, vol. 1, no. 1, 2012.

[7] S. Hastanto, "Tembang Macapat in Central Java," in Proceedings of the Royal Musical Association, 1983, vol. 110, no. 1, pp. 118-127.

[8] M. H. Effendy, "Local Wisdom Dalam Tembang Macapat Madura," Okara J. Bhs. Dan Sastra, vol. 9, no. 1, pp. 55-72, 2015.

[9] M. M. Jamil, Ed., Syi'iran dan Transmisi Ajaran Islam di Jawa. Semarang: Walisongo Press, 2010.

[10] E. Susanto, "Tembhang Macapat Dalam Tradisi Islami Masyarakat Madura," IBDA J. Kaji. Islam Dan Budaya, vol. 14, no. 2, Art. no. 2, Oct. 2016, doi: 10.24090/ibda.v14i2.682.

[11] S. Darnawi, Pengantar puisi Djawa. Balai Pustaka, 1964.

[12] K. Saddhono and D. Pramestuti, "Sekar Macapat Pocung: Study of Religious Values based on The Local Wisdom of Javanese Culture," El Harakah, vol. 20, no. 1, p. 15, 2018.

[13] B. Arps, "The Power of the Heart that Blazes in the World: An Islamic Theory of Religions in Early Modern Java," Indones. Malay World, vol. 47, no. 139, pp. 308334, 2019.

[14] N. Florida, "Writing Traditions in Colonial Java: the Question of Islam," in Cultures of Scholarship, Ann Arbor MI: University of Michigan Press, 1997, pp. 187-217. 
[15] O. Fathurahman, "Itḥāf al-dhakī by Ibrāhīm al-Kūrān̄i A Commentary of Waḥdat alWujūd for Jāwī Audiences," 2011.

[16] Otto Loth, A Catalogue of the Arabic Manuscripts in the Library of the India Office, vol. 1. London: Stephen Austin and Sons, 1877.

[17] A. H. Johns, The Gift Addressed to the Spirit of the Prophet. Canberra: Australian National University, 1965.

[18] A. Azra, Jaringan ulama: Timur Tengah dan kepulauan Nusantara abad XVII \& XVIII : akar pembaruan Islam Indonesia. Jakarta: Kencana, 2004.

[19] Z. K. Umam, "The Life, Circle, and Forum of Ahmad al-Qushashi," Life, 2016.

[20] P. Voorhoeve, Handlist of Arabic Manuscripts in the library of the University of Leiden and Other Collections in the Netherlands. Leiden: Bibliotheca Universitatis, 1957.

[21] Jan Just Witkam, Inventory of The Oriental Manuscripts of The Library of The University of Leiden, vol. 6. Leiden: Ter Lugt, 2007.

[22] Z. Dhofier, "The Pesantren Tradition: the Role of the Kyai in the Maintenance of Traditional Islam in Java," Unpublished Dissertation, The Australian National University, Canberra, 1999.

[23] S. Umam, "God's Mercy is Not Limited to Arabic Speakers: Reading Intellectual Biography of Muhammad Salih Darat and His Pegon Islamic Texts," Stud. Islam., vol. 20, no. 2, pp. 243-273, 2014.

[24] M. van Bruinessen, Kitab Kuning, Pesantren dan Tarekat, Revision. Yogyakarta: Gading Publishing, 2012.

[25] I. Al-Kurani and O. Fathurrahman, Ithāaf Al-Dhakī: Tafsir Wahdatul Wujud bagi Muslim Nusantara. Jakarta: Mizan, 2012.

[26] M. A. Yahya, Suntingan dan Terjemah Manuskrip Al-Mawahib Al-Mustarsalah ala AlTuhfah Al-Mursalah. Jakarta: Perpustakaan Nasional Republik Indonesia, 2018. 